\title{
Rancang Bangun Pembangkit Listrik Tenaga Gelombang Laut Menggunakan Sistem Oscillating Water Column
}

\author{
Siti Rohmaniatul Adafiah ${ }^{\text {* }}$, Artdhita Fajar Pratiwi², Saepul Rahmat ${ }^{1}$ \\ ${ }^{1}$ Program Studi Teknik Listrik, Politeknik Negeri Cilacap \\ ${ }^{2}$ Program Studi Teknik Elektronika, Politeknik Negeri Cilacap \\ ${ }_{1,2}$ Jln. Dr. Soetomo No.1 Sidakaya, Kabupaten Cilacap, Indonesia \\ E-mail: sitirohmanitul888@gmail.com ${ }^{1}$, art_dhita@yahoo.com ${ }^{2}$, saepulrahmat06@gmail.com ${ }^{3}$
}

\section{Info Naskah:}

Naskah masuk: 22 Oktober 2020

Direvisi: 17 Maret 2021

Diterima: 18 Maret 2021

\begin{abstract}
Abstrak
Pembangkit listrik tenaga gelombang laut merupakan salah satu pembangkit yang memanfaatkan gelombang air laut sebagai energi utama. Meskipun jumlah energi melimpah, tetapi di Indonesia pemanfaatan gelombang laut sebagai pembangkit listrik masih sedikit. Hal itu disebabkan karena kurangnya sumber daya manusia untuk mengelola energi gelombang air laut. Penelitian penelitian mengenai Oscillating Water Column telah banyak dilakukan, namun hanya sebatas studi potensi atau kelayakan untuk dipasang di pesisir pantai. Oleh karena itu fokus penelitian ini adalah membuat rancang bangun pembangkit listrik tenaga gelombang laut dengan sistem oscillating water column. Proses kerja alat dimulai dengan mengatur pwm untuk menggerakan motor power window yang sudah terhubung dengan lengan ombak. Saat lengan ombak bergerak maju mundur maka akan menghasilkan gelombang laut buatan. Gelombang buatan didalam chamber menghasilkan udara bertekanan, udara yang dihasilkan akan dimanfaatkan untuk memutar sudu sudu turbin yang telah terhubung dengan generator sehingga menghasilkan energi listrik. Tegangan dan arus terbesar didapatkan ketika kecepatan angin di chamber mencapai 7,7 m/s dan kecepatan putar puli terbesar yaitu $31,9 \mathrm{rpm}$ pada level air $17 \mathrm{~cm}$ adalah sebesar 3,03 V DC dan 6,07 mA. Hasil pengujian tersebut membuktikan bahwa potensi gelombang air dapat dimanfaatkan untuk menghasilkan listrik. Pengembangan kapasitas pembangkit listrik tenaga gelombang laut dapat dilakukan dengan mengganti dimensi turbin dan menambah kapasitas generator.
\end{abstract}

\section{Keywords:}

PLTGL;

wells turbin;

arduino UNO;

INA 219 sensor.

\begin{abstract}
Ocean wave power plant is one of the plants that uses sea waves as the main energy. Although the amount of energy is abundant, in Indonesia the use of sea waves as electricity generators is still small. This is due to the lack of human resources to manage the wave energy of sea water. Many research studies on the Oscillating Water Column have been carried out, but it is only limited to a potential or feasibility study to be installed on the coast. Therefore, the focus of this research is to design a sea wave power plant with an oscillating water column system. The working process of the tool begins by adjusting the pwm to drive the motor power window which is connected to the wave arm. When the wave arm moves back and forth, it will produce artificial ocean waves. Artificial waves in the chamber produce compressed air, the air produced is used to rotate the turbine blades that have been connected to the generator to produce electrical energy. The greatest voltage and current is obtained when the wind speed reaches $7.7 \mathrm{~m} / \mathrm{s}$ and the largest pulley rotating speed reaches $31,9 \mathrm{rpm}$ at the $17 \mathrm{~cm}$ water level, which is $3.03 \mathrm{~V} \mathrm{DC}$ and $6,07 \mathrm{~mA}$. The test results prove that the potential of water waves can be used to generate electricity The development of the capacity of ocean wave power plants can be done by changing the dimensions of the turbines and increasing the capacity of the generator.
\end{abstract}

*Penulis korespondensi:

Siti Rohmaniatul Adafiah

E-mail: sitirohmanitul888@gmail.com 


\section{Pendahuluan}

Permintaan energi terus meningkat seiring dengan perkembangan kebutuhan manusia. Untuk mengatasi habisnya energi fosil, masyarakat telah memanfaatkan berbagai macam penggunaan energi. Salah satu solusinya adalah dengan menggunakan sumber energi baru terbarukan seperti matahari, angin, gelombang laut dan air. Padahal, potensi energi air sangat besar, hingga saat ini pemanfaatannya belum maksimal. Oleh karena itu, harus dikembangkan untuk memenuhi kebutuhan daya di daerah pedesaan terpencil, dan harus dikembangkan sebagai sistem interkoneksi dengan jaringan PLN yang ada. [1-2].

Saat ini terdapat banyak pembangkit listrik yang ramah lingkungan, antara lain: sel surya, pembangkit listrik mikrohidro, pembangkit listrik tenaga panas bumi, dll. Salah satu jenis pembangkit listrik yang dapat digunakan di Indonesia adalah pembangkit listrik tenaga gelombang laut. Gelombang laut merupakan salah satu bentuk energi terbarukan yang dibentuk oleh angin yang bertiup di permukaan laut [3-7].

Penelitian penelitian mengenai Oscillating Water Column telah banyak dilakukan, namun hanya sebatas studi potensi atau kelayakan untuk dipasang di sepanjang pesisir pantai [8-14]. Belum terdapat penelitian yang mengkaji standar ukuran kolam prototipe untuk menghasilkan gelombang yang dapat menghasilkan tenaga listrik atau spesifikasi teknis peralatan jika sistem Oscillating Water Column akan dipasang di tepi pantai [15]. Penelitian [16] melakukan simulasi pemasangan pembangkit hybrid antara pembangkit listrik tenaga angin dan oscillating water column. Penelitian lain sejenis [17] melakukan studi kelayakan penggunaan pembangkit listrik gelombang laut dengan metode piezoelectric.

Tujuan dari penelitian ini adalah membuat rancang bangun pembangkit listrik tenaga gelombang laut (PLTGL) menggunakan sistem Oscillating Water Column. Rancang bangun ini diharapkan menjadi rekomendasi pengembangan penelitian dengan memanfaatkan gelombang laut menggunakan sistem kolom air berosilasi atau oscilating water column (OWC) di wilayah Cilacap.

\section{Metode}

Tahapan penelitian yang dilakukan diperlihatkan pada Gambar 1, merupakan diagram alir penelitian dimulai dari review penelitian sejenis yang diambil dari studi literatur, kemudian melakukan perencanaan alat, pengujian alat, pengambilan data, analisis data dan kesimpulan penelitian. Sumber pustaka dapat berupa buku, prosiding, dan jurnal. Data yang diperoleh dapat berupa bacaan dan data hasil ukur.

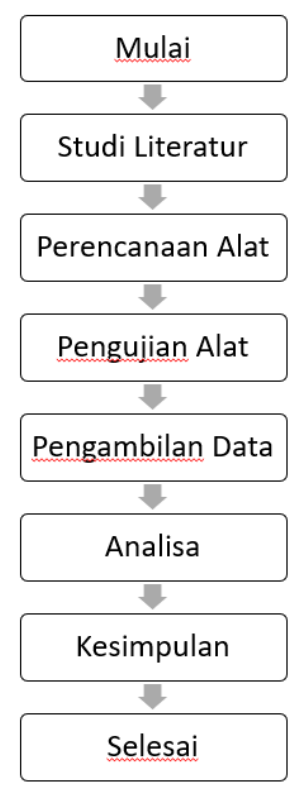

Gambar 1. Diagram Alir Penelitian

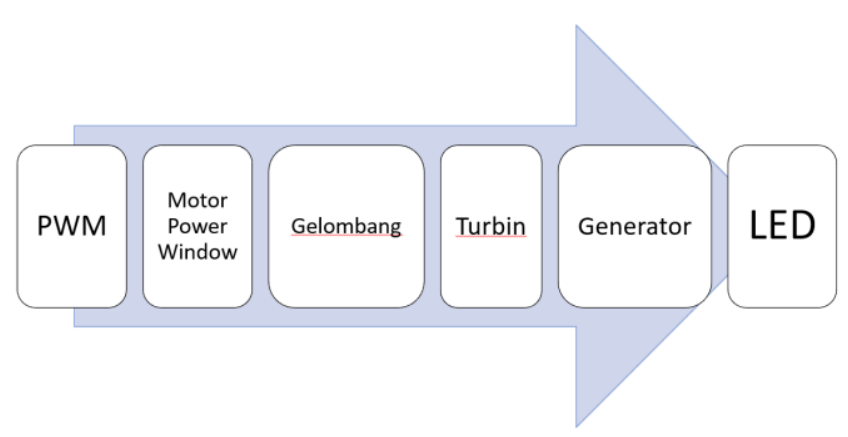

Gambar 2. Blok Diagram PLTGL

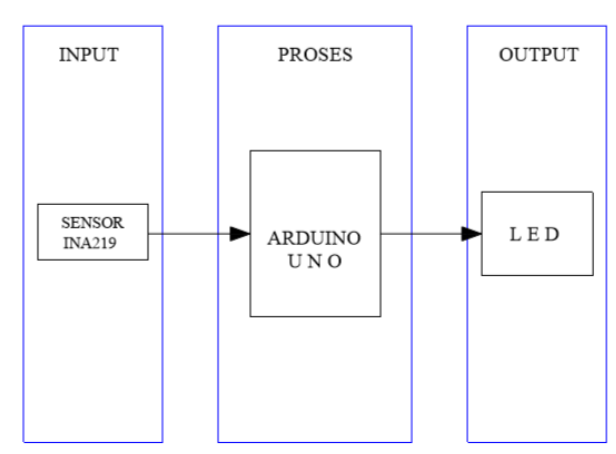

Gambar 3. Blok Diagram Sistem Monitoring

\subsection{Perancangan PLTGL}

Tahap perancangan PLTGL sistem OWC dimulai dari perancangan diagram blok. Sistem yang digunakan terbagi menjadi dua sistem. Sistem pertama menjelaskan bagaimana proses gelombang air diubah menjadi energi listrik. Sistem kedua mendeskripsikan sistem monitoring arus dan tegangan pada sistem PLTG OWC menggunakan mikrokontroler Arduino UNO. Pembacaan sensor akan ditampilkan di LCD. 
Tahapan selanjutnya akan dijelaskan secara detail pada flowchart.

Tahapan berikutnya adalah proses penyusunan diagram blok untuk menggambarkan proses kerja alat. Diagram blok ini nantinya akan digunakan sebagai gambaran umum desain PLTGL sistem OWC. Penggambaran diagram blok yang akan digunakan pada sistem, dijelaskan pada Gambar 2 dan Gambar 3.

Proses kerja alat diawali dengan mengatur pwm untuk menggerakkan motor power window yang terhubung ke rocker arm. Ketika lengan gelombang bergerak maju mundur, gelombang buatan dihasilkan. Gelombang buatan di dalam ruangan menghasilkan udara terkompresi, dan udara yang dihasilkan digunakan untuk memutar bilah turbin yang terhubung ke generator untuk menghasilkan listrik untuk menyalakan LED. Sistem monitoring pada perancangan PLTGL menggunakan sistem OWC yaitu menggunakan mikrokontroler Arduino UNO dan sensor INA 129 untuk mengetahui arus dan tegangan yang dibangkitkan oleh generator dengan beban LED. Pembacaan tegangan dan arus akan ditampilkan di LCD.

\subsection{Diagram Alir (Flow Chart)}

Pembuatan diagram alir untuk menggambarkan secara umum bagaimana skema alat tersebut bekerja dan menjelaskan proses konversi energi gelombang air menjadi energi listrik. Diagram alir desain pembangkit listrik tenaga gelombang laut sistem OWC ditunjukkan pada Gambar 4 berikut ini.

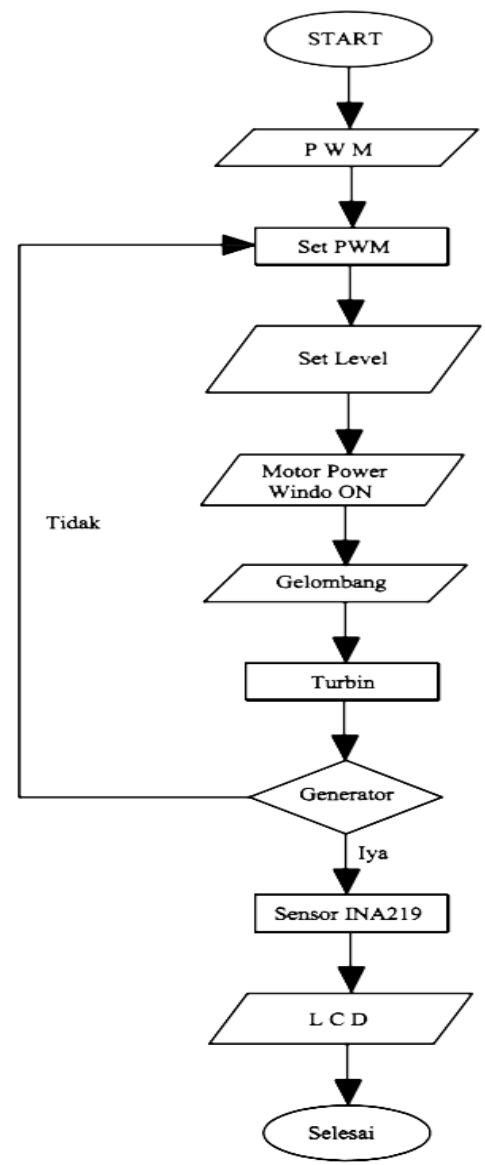

Gambar 4. Diagram Alir PLTGL
Untuk memperjelas fungsi -fungsi peralatan pada diagram alir maka akan dijelaskan seperti berikut :

1) DC Speed Regulator / PWM Control, digunakan untuk mengatur kecepatan motor power window.

2) Motor Power Window, digunakan untuk membuat gelombang buatan. Poros disambungkan dengan lengan ombak sehingga menyebabkan gerak maju mundur dan akan membuat gelombang buatan pada air seiring dengan gerakan pada poros.

3) Turbin Angin, alat ini akan digerangan oleh udara yang dihasilkan oleh gelombang buatan.

4) Generator DC, Digunakan untuk merubah tenaga mekanis yang diperoleh dari putaran turbin angin menjadi tenaga listrik arus DC

5) Sensor INA 219, Sensor ini digunakan untuk INA 219 merupakan sensor arus yang juga bisa mengukur nilai beda tegangan suatu rangkaian. Sensor ini digunakan pada sistem untuk mendeteksi nilai tegangan dan arus yang dihasilkan oleh generator dan beban.

6) Arduino Uno R3, Digunakan sebagai pusat kontroler yang memproses input dari sensor INA219 sehingga dapat memerintah output.

7) LCD, berfungsi untuk menampilkan informasi nilai beda tegangan yang diperoleh dan arus yang mengair.

Alur kerja pembangkit ini dimulai dengan penggunaan motor power window sebagai pembangkit gelombang yang diatur dengan kontrol PWM. Motor listrik yang berputar mengubah energi listrik menjadi energi mekanik, yang menggerakkan lengan gelombang yang bergerak maju mundur dan mendorong air di dalam wadah, menyebabkan riak dan mengubahnya menjadi gelombang buatan. Gelombang yang menghasilkan udara digunakan untuk memutar turbin melalui ruang, dan turbin berputar di sekitar porosnya, yang menyebabkan generator berputar dan menghasilkan listrik. Keluaran generator ini akan dimonitor oleh mikrokontroler Arduino. Objek yang dipantau antara lain tegangan dan arus. Selain itu, hasil pemantauan ditampilkan di LCD. Gambar 5 adalah desain PLTGL dari sistem OWC.

\section{Hasil dan Pembahasan}

Setelah implementasi perancangan alat tersebut, maka perlu dilakukan pengujian untuk mengetahui dan menganalisis keberhasilan, kelemahan dan keterbatasan perancangan PLTGL sistem OWC.

\subsection{Pengujian Rancang Bangun PLTGL sistem OWC}

Pembahasan merupakan analisis hasil pengujian perancangan PLTGL sistem OWC, yang dapat berupa analisis perhitungan dan analisis pembacaan alat ukur. Perhitungan dan analisis pengukuran akan disajikan dalam bentuk tabel dan grafik. Pengujian seperti pengujian kekuatan mekanis pembuat ombak dan pengukuran arus dan tegangan pada level air yang berbeda juga dilakukan. 


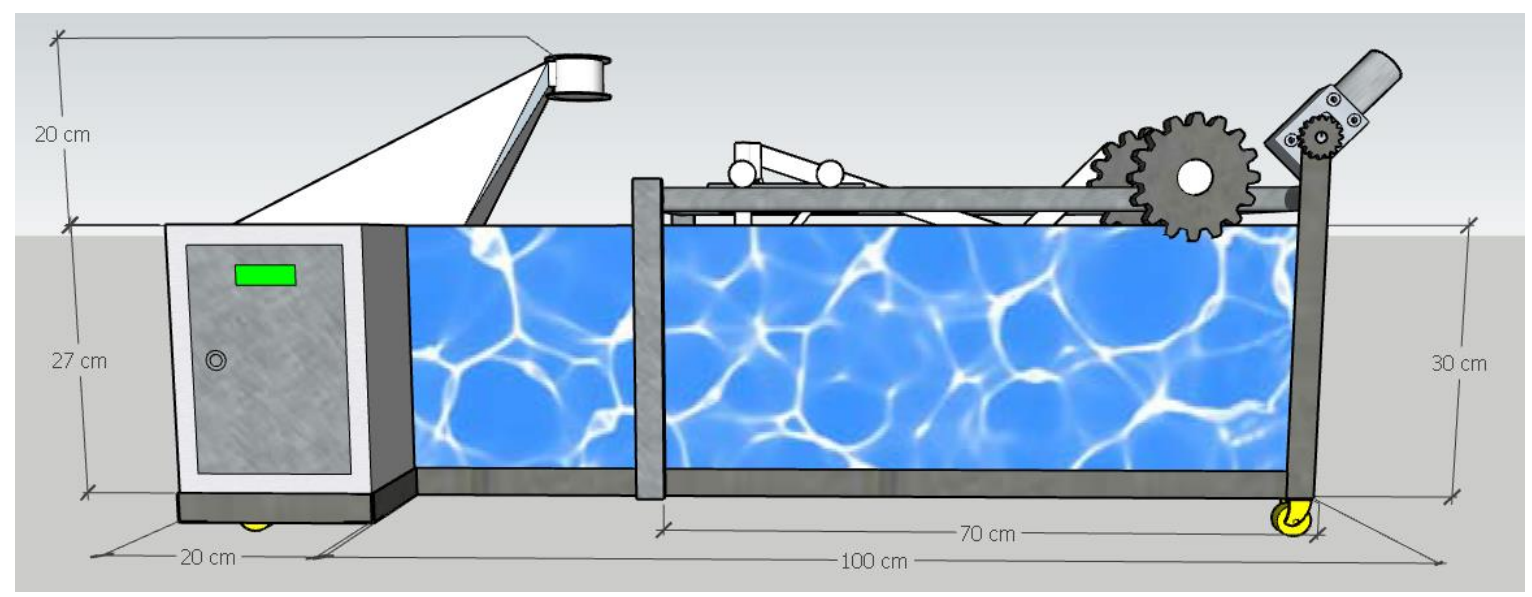

Gambar 5. Desain Rancang Bangun PLTGL OWC

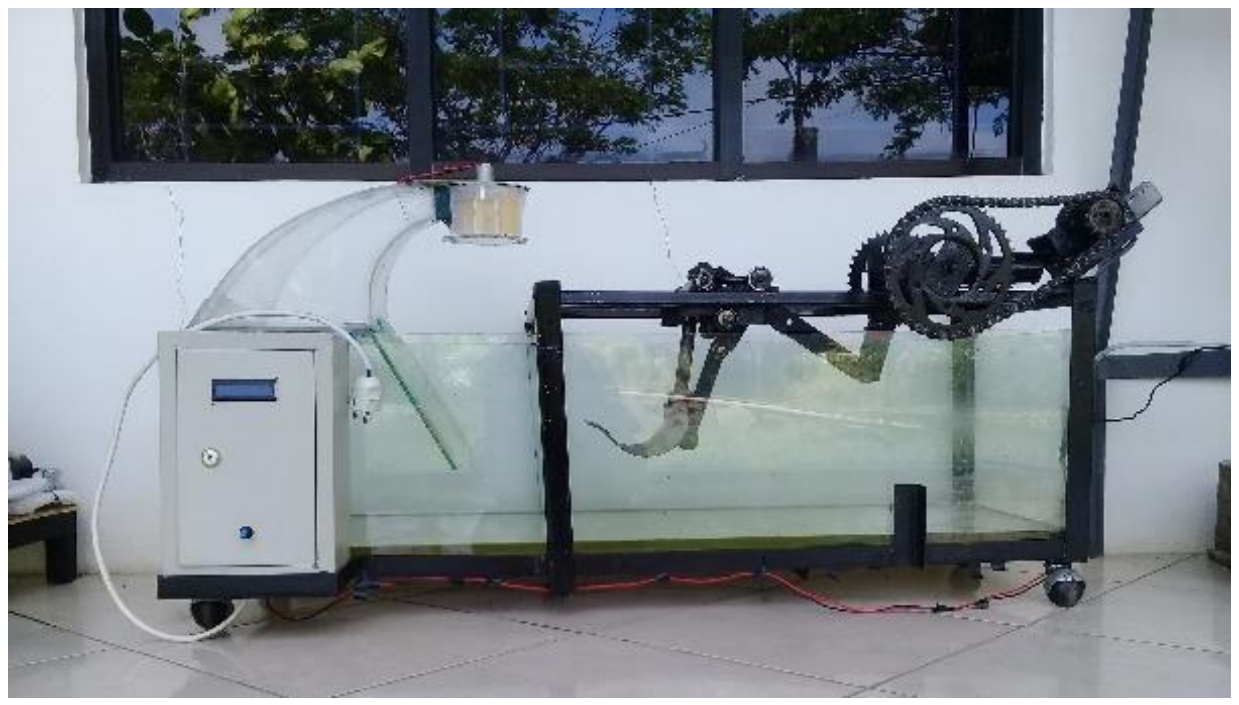

Gambar 6. Rancang Bangun PLTGL OWC

Pada Gambar 6 merupakan prototipe rancangan sistem PLTGL OWC. Kolam penampung air terbuat dari kaca dengan dimensi panjang $120 \mathrm{~cm}$, lebar $40 \mathrm{~cm}$ dan tinggi 30 $\mathrm{cm}$. Tegangan dan arus yang dihasilkan berupa DC. Sistem PLTGL OWC juga dilengkapi dengan monitor arus dan tegangan, sehingga arus dan tegangan yang dihasilkan dapat ditampilkan di layar LCD. Untuk pembangkit gelombang, PWM dapat digunakan untuk mengatur kecepatan.

\subsection{Pengujian Pengaduk Ombak}

Dalam pengujian ini kecepatan putar puli akan diukur menggunakan tachometer, sedangkan untuk mengukur kecepatan angin menggunakan anemometer, percobaan dilakukan sebanyak 5 kali. Dari hasil pengujian diperoleh data-data seperti pada Tabel 1 .

Tujuan pengujian ini adalah untuk mengetahui kinerja pengaduk ombak, kecepatan putar puli, dan kecepatan angin yang dihasilkan. Berdasarkan penelitian ini didapatkan kecepatan putar puli tertinggi 31,9 Rpm dan terendah 24,7 Rpm, sedangkan untuk kecepatan angin tertinggi 31,9 Rpm dan terendah 24,38 Rpm. Hubungan antara kecepatan putar puli dengan kecepatan angin pada chamber adalah berbanding lurus. Semakin besar torsi dan cepat puli berputar, maka kecepatan angin yang dihasilkan semakin besar, sehingga akan berpengaruh terhadap kenaikan tegangan dan arus pada generator.

Tabel 1. Pengujian pengaduk ombak

\begin{tabular}{llcc}
\hline No. & Pengaduk & $\begin{array}{c}\text { Anemometer } \\
(\mathbf{m} / \mathbf{s})\end{array}$ & $\begin{array}{c}\text { Tachometer } \\
(\mathbf{R p m})\end{array}$ \\
\hline 1 & Maju & 7,7 & 31,9 \\
2 & Mundur & 5,3 & 28,6 \\
3 & Maju & 6,5 & 30,5 \\
4 & Mundur & 4,2 & 26,1 \\
5 & Maju & 4,1 & 24,7 \\
\hline & Rata-rata & 5,56 & 28,38 \\
\hline
\end{tabular}

\subsection{Pengukuran Arus dan Tegangan}

Pengukuran arus dan tegangan diukur dengan beban LED menggunakan sensor INA219 dan multimeter sebagai pembanding. Pengujian ini dilakukan pada level air yang berbeda. 
Pengukuran Arus Level $13 \mathrm{~cm}$ bertujuan untuk mengetahui hasil keluaran arus dari generator. Berdasarkan hasil penelitian ini didapatkan jumlah arus tertinggi adalah $0,90 \mathrm{~mA}$, terendah $0,30 \mathrm{~mA}$, hasil pengujian dapat dilihat pada Tabel 2. Hubungan arus dengan jumlah percobaan yang dilakukan dijelaskan melalui grafik pada Gambar 7 Berdasarkan grafik diatas dapat dilihat bahwa hasil pengukuran arus antara sensor INA dan multimeter tetap linier sehingga perhitungan error nilai arus di sensor INA dan multimeter tidak terlalu besar.

Tabel 2 Hasil Pengukuran Arus Level $13 \mathrm{~cm}$

\begin{tabular}{ccccc}
\hline No. & Percobaan & $\begin{array}{c}\text { Sensor } \\
(\mathbf{m A})\end{array}$ & $\begin{array}{c}\text { Multimeter } \\
(\mathbf{m A})\end{array}$ & $\begin{array}{c}\text { Selisih } \\
(\mathbf{m A})\end{array}$ \\
\hline 1 & Percobaan 1 & 0,90 & 0,67 & 0,23 \\
2 & Percobaan 2 & 0,70 & 0,57 & 0,13 \\
3 & Percobaan 3 & 0,60 & 0,56 & 0,04 \\
4 & Percobaan 4 & 0,40 & 0,40 & 0 \\
5 & Percobaan 5 & 0,30 & 0,32 & 0,02 \\
\hline \multicolumn{2}{c}{ Rata - rata } & 0,58 & 0,50 & 0,08 \\
\hline
\end{tabular}

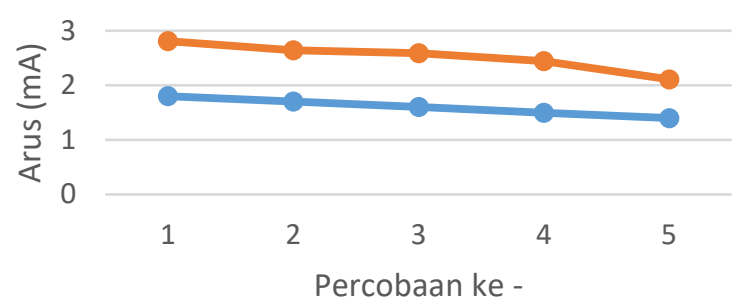

$\longrightarrow$ Sensor $(\mathrm{mA}) \quad$ Multimeter $(\mathrm{mA})$

Gambar 7. Grafik Pengukuran Arus

Tabel 3. Pengukuran Arus Level $15 \mathrm{~cm}$

\begin{tabular}{ccccc}
\hline No & Percobaan & $\begin{array}{c}\text { Sensor } \\
(\mathbf{m A})\end{array}$ & $\begin{array}{c}\text { Multimeter } \\
(\mathbf{m A})\end{array}$ & $\begin{array}{c}\text { Selisih } \\
(\mathbf{m A})\end{array}$ \\
\hline 1 & Percobaan 1 & 2,40 & 3,37 & 0,97 \\
2 & Percobaan 2 & 2,30 & 2,93 & 0,63 \\
3 & Percobaan 3 & 2,15 & 2,8 & 0,65 \\
4 & Percobaan 4 & 1,90 & 2,64 & 0,74 \\
5 & Percobaan 5 & 1,80 & 2,48 & 0,68 \\
\hline \multicolumn{2}{l}{ Rata - rata } & 2,08 & 2,85 & 0,77 \\
\hline
\end{tabular}

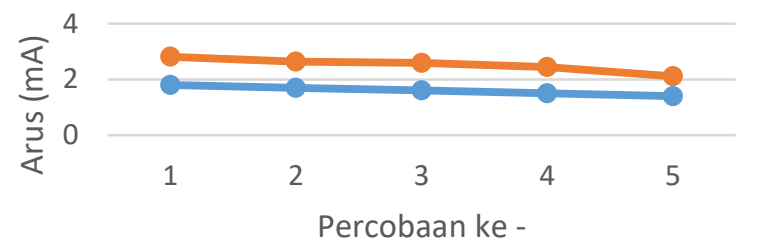

-Sensor $(\mathrm{mA}) \longrightarrow$ Multimeter $(\mathrm{mA})$

Gambar 8. Grafik Pengukuran Arus
Berdasarkan pengukuran Arus Level $15 \mathrm{~cm}$ hasil penelitian ini didapatkan jumlah arus tertinggi 3,37 mA, terendah 1,90 mA. Hasil pengujian dapat dilihat pada Tabel 3. Berdasarkan tabel didapatkan grafik pada Gambar 8 yang menjelaskan antara hubungan nilai arus dengan jumlah percobaan yang dilakukan.

Hubungan arus dengan jumlah percobaan yang dilakukan dijelaskan melalui grafik pada Gambar 8 . Berdasarkan grafik diatas dapat dilihat bahwa hasil pengukuran arus antara sensor INA dan multimeter tetap linier sehingga perhitungan error nilai arus di sensor INA dan multimeter yang lebih besar dibandingkan pengujian arus dengan level $13 \mathrm{~cm}$. Hal ini diakibatkan oleh kecepatan putar puli pembuat gelombak semakin berkurang akibat bertambahnya volume air yang digunakan. Volume air yang bertambah membuat gaya dorong terhadap air yang dihasilkan semakin kecil sehingga udara yang masuk ke chamber pun sedikit dan mengakibatkan kecepatan bilah turbin tidak optimal.

Pada proses pengukuran Arus Level $20 \mathrm{~cm}$, berdasarkan hasil penelitian ini didapatkan arus tertinggi adalah $2,81 \mathrm{~mA}$, terendah $2,11 \mathrm{~mA}$ dan rata-rata error $0,36 \%$. Hasil pengujian dapat dilihat pada Tabel 4. Berdasarkan tabel didapatkan grafik pada Gambar 9 yang menjelaskan antara hubungan nilai arus dengan jumlah percobaan yang dilakukan.

Tabel 4. Pengukuran Arus Level $20 \mathrm{~cm}$

\begin{tabular}{ccccc}
\hline No. & Percobaan & $\begin{array}{c}\text { Sensor } \\
(\mathbf{m A})\end{array}$ & $\begin{array}{c}\text { Multimeter } \\
(\mathbf{m A})\end{array}$ & $\begin{array}{c}\text { Selisih } \\
(\mathbf{m A})\end{array}$ \\
\hline 1 & Percobaan 1 & 1,80 & 2,81 & 1,01 \\
2 & Percobaan 2 & 1,70 & 2,64 & 0,94 \\
3 & Percobaan 3 & 1,60 & 2,59 & 0,99 \\
4 & Percobaan 4 & 1,50 & 2,44 & 0,94 \\
5 & Percobaan 5 & 1,40 & 2,11 & 0,71 \\
\hline \multicolumn{2}{c}{ Rata - rata } & 1,6 & 2,51 & 0,91 \\
\hline
\end{tabular}

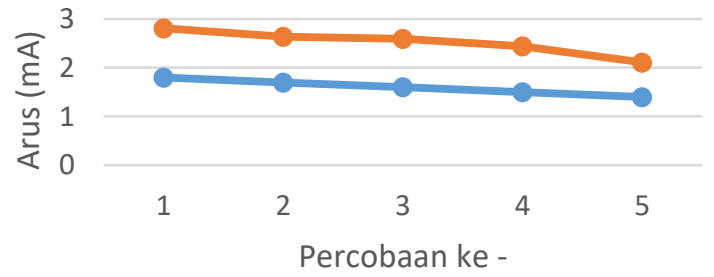

$\longrightarrow$ Sensor (mA) $\quad \longrightarrow$ Multimeter $(\mathrm{mA})$

Gambar 9. Grafik Pengukuran Arus

Hubungan arus dengan jumlah percobaan yang dilakukan dijelaskan melalui grafik pada Gambar 9. Berdasarkan Gambar 9 dapat dilihat bahwa hasil pengukuran arus antara sensor INA dan multimeter tetap linier sehingga perhitungan error nilai arus di sensor INA dan multimeter tidak jauh berbeda. Hal ini diakibatkan oleh motor power berada pada PWM maksimum sehingga membuat gaya dorong terhadap air yang dihasilkan berbanding lurus dengan volume air yang berada pada keadaan maksimal juga. 
Pengukuran selanjutnya adalah melakukan Pengukuran Tegangan Level $13 \mathrm{~cm}$. Tujuan dari pengujian ini adalah untuk mengetahui hasil keluaran tegangan dari generator. Berdasarkan penelitian ini didapatkan jumlah tegangan tertinggi adalah 1,9 V DC, terendah 0,89 V DC. Hasil pengujian dapat dilihat pada Tabel 5. Berdasarkan tabel didapatkan grafik pada Gambar 10 yang menjelaskan antara hubungan nilai tegangan generator yang dibangkitkan dengan jumlah percobaan yang dilakukan.

Tabel 5. Hasil Pengukuran Tegangan $13 \mathrm{~cm}$

\begin{tabular}{ccccc}
\hline \multirow{2}{*}{ No. } & Percobaan & $\begin{array}{c}\text { Sensor } \\
\text { (V DC) }\end{array}$ & $\begin{array}{c}\text { Multimeter } \\
\text { (V DC) }\end{array}$ & $\begin{array}{c}\text { Selisih } \\
\text { (V DC) }\end{array}$ \\
\hline 1 & Percobaan 1 & 1,04 & 1,9 & 0,86 \\
2 & Percobaan 2 & 1,04 & 1,7 & 0,53 \\
3 & Percobaan 3 & 0,98 & 1,6 & 0,56 \\
4 & Percobaan 4 & 0,97 & 1,5 & 0,66 \\
5 & Percobaan 5 & 0,89 & 1,4 & 0,42 \\
\hline \multicolumn{2}{l}{ Rata - rata } & 1,02 & 1,48 & 0,46 \\
\hline
\end{tabular}

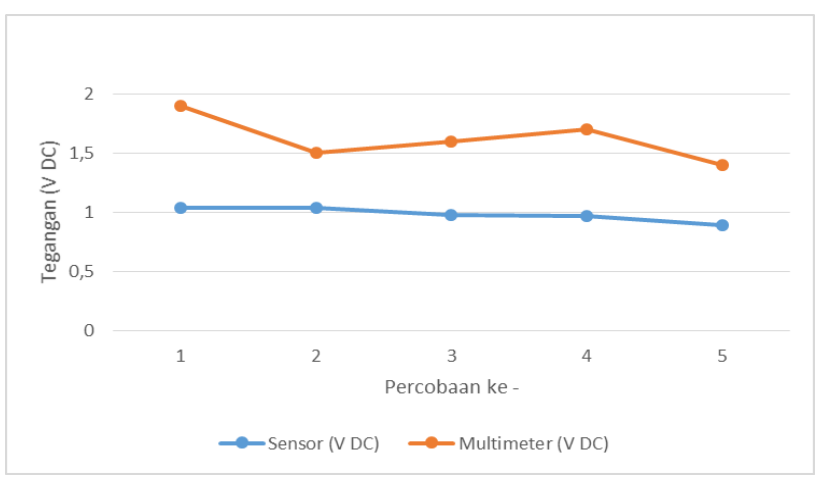

Gambar 10. Grafik Pengukuran Tegangan (V DC)

Tabel 6. Hasil Pengukuran Tegangan level $15 \mathrm{~cm}$

\begin{tabular}{ccccc}
\hline No. & Percobaan & $\begin{array}{c}\text { Sensor } \\
\text { (V DC) }\end{array}$ & $\begin{array}{c}\text { Multimeter } \\
\text { (V DC) }\end{array}$ & $\begin{array}{c}\text { Selisih } \\
\text { (V DC) }\end{array}$ \\
\hline 1 & Percobaan 1 & 1,97 & 1,99 & 0,02 \\
2 & Percobaan 2 & 1,74 & 1,83 & 0,09 \\
3 & Percobaan 3 & 1,69 & 1,76 & 0,07 \\
4 & Percobaan 4 & 1,56 & 1,67 & 0,11 \\
5 & Percobaan 5 & 1,46 & 1,62 & 0,16 \\
\hline \multicolumn{2}{r}{ Rata - rata } & 1,68 & 1,77 & 0,09 \\
\hline
\end{tabular}

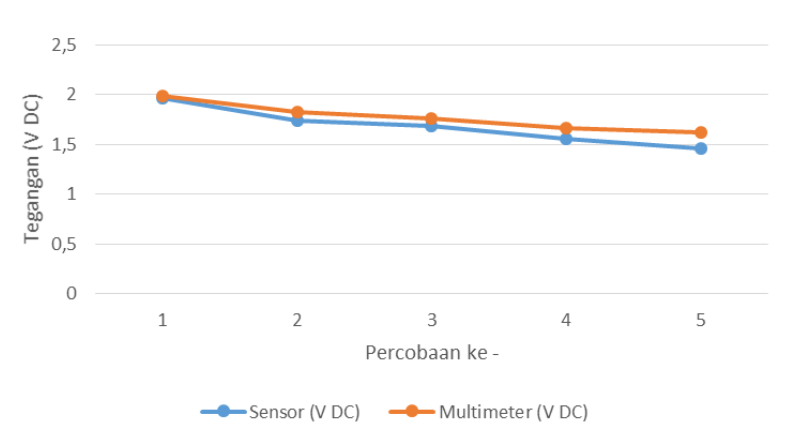

Gambar 11. Grafik Pengukuran Tegangan
Hubungan tegangan dengan jumlah percobaan yang dilakukan dijelaskan melalui grafik pada Gambar 10 Berdasarkan grafik diatas dapat dilihat bahwa hasil pengukuran arus antara sensor INA dan multimeter tetap linier sehingga perhitungan error nilai arus di sensor INA dan multimeter tidak terlalu besar.

Pada Pengukuran Tegangan Level $15 \mathrm{~cm}$ didapatkan tegangan tertinggi adalah $1,99 \mathrm{~V} \mathrm{DC}$, terendah 1,62 V DC dan Hasil pengujian dapat dilihat pada Tabel 6. Berdasarkan tabel didapatkan grafik pada Gambar 11 yang menjelaskan antara hubungan nilai arus dengan jumlah percobaan yang dilakukan.

Hubungan tegangan dengan jumlah percobaan yang dilakukan dijelaskan melalui grafik pada Gambar 11 . Berdasarkan grafik diatas dapat dilihat bahwa hasil pengukuran tegangan antara sensor INA dan multimeter tetap linier sehingga perhitungan error nilai tegangan di sensor INA dan multimeter yang lebih besar dibandingkan pengujian arus dengan level $13 \mathrm{~cm}$. Hal ini diakibatkan oleh kecepatan putar puli pembuat gelombak semakin berkurang akibat bertambahnya volume air yang digunakan. Volume air yang bertambah membuat gaya dorong terhadap air yang dihasilkan semakin kecil sehingga udara yang masuk ke chamber pun sedikit dan mengakibatkan kecepatan bilah turbin tidak optimal.

Untuk Pengukuran Tegangan Level $20 \mathrm{~cm}$, berdasarkan hasil penelitian ini didapatkan tegangan tertinggi adalah 1,98V DC, terendah 1,66 V DC. Hasil pengujian dapat dilihat pada Tabel 7. Berdasarkan tabel 7 didapatkan grafik pada Gambar 12 yang menjelaskan antara hubungan nilai arus dengan jumlah percobaan yang dilakukan.

Tabel 7. Pengukuran Tegangan Level $20 \mathrm{~cm}$

\begin{tabular}{ccccc}
\hline No. & Percobaan & $\begin{array}{c}\text { Sensor } \\
\text { (V DC) }\end{array}$ & $\begin{array}{c}\text { Multimeter } \\
\text { (V DC) }\end{array}$ & $\begin{array}{c}\text { Selisih } \\
\text { (V DC) }\end{array}$ \\
\hline 1 & Percobaan 1 & 1,94 & 1,98 & 0,04 \\
2 & Percobaan 2 & 1,92 & 1,94 & 0,02 \\
3 & Percobaan 3 & 1,83 & 1,88 & 0,05 \\
4 & Percobaan 4 & 1,70 & 1,74 & 0,04 \\
5 & Percobaan 5 & 1,66 & 1,66 & 0 \\
\hline \multicolumn{2}{r}{ Rata - rata } & 1,81 & 1,84 & 0,03 \\
\hline
\end{tabular}

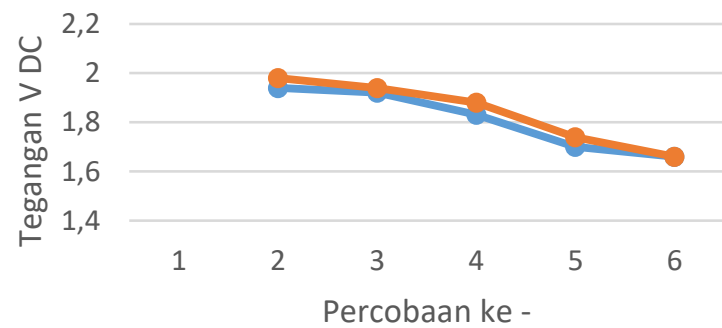

$\longrightarrow$ Sensor (V DC) $\longrightarrow$ Multimeter (V DC)

Gambar 12. Grafik Pengukuran Tegangan 
Hubungan tegangan dengan jumlah percobaan yang dilakukan dijelaskan melalui grafik pada Gambar 12. Berdasarkan grafik diatas dapat dilihat bahwa hasil pengukuran tegangan antara sensor INA dan multimeter tetap linier sehingga perhitungan error nilai arus di sensor INA dan multimeter tidak jauh berbeda. Hal ini diakibatkan oleh motor power berada pada PWM maksimum sehingga membuat gaya dorong terhadap air yang dihasilkan menjadi besar sehingga akan menghasilkan gelombang yang meniupkan udara bertekanan untuk memutar turbin secara optimal. Hal inilah yang menyebabkan tegangan keluaran generator berada pada kondisi maksimum

\subsection{Ketinggian Air Terhadap Arus dan Tegangan}

Dari hasil pengujian Pengukuran tegangan dan arus pada level ketinggian air $10-20 \mathrm{~cm}$ diperoleh arus maksimal pada ketinggian air $17 \mathrm{~cm}$ yaitu $6,07 \mathrm{~mA}$ dan tegangan maksimal pada ketinggian air $17 \mathrm{~cm}$ yaitu 3,03 V DC. Namun motor power window mudah panas dan pelan saat menggerakan lengan ombak pada level air $17 \mathrm{~cm}$. data dapat dilihat pada Tabel 8. Untuk grafik hubungan ketinggian air terhadap arus dan tegangan dapat dilihat pada Gambar 13 dan Gambar 14.

Tabel 8. Pengukuran Rata-rata Arus dan Tegangan

\begin{tabular}{cccc}
\hline No. & $\begin{array}{c}\text { Tinggi Air } \\
(\mathbf{c m})\end{array}$ & $\begin{array}{c}\text { Arus } \\
(\mathbf{m A})\end{array}$ & $\begin{array}{c}\text { Tegangan } \\
(\mathbf{V ~ D C})\end{array}$ \\
\hline 1 & 10 & 0 & 0 \\
2 & 11 & 0 & 0 \\
3 & 12 & 0 & 0 \\
4 & 13 & 0,5 & 1,48 \\
5 & 14 & 1,7 & 1,45 \\
6 & 15 & 2,85 & 1,77 \\
7 & 16 & 3,18 & 1,72 \\
8 & 17 & 6,07 & 3,03 \\
9 & 18 & 5,64 & 2,83 \\
10 & 19 & 3,29 & 2,39 \\
11 & 20 & 2,51 & 1,84 \\
\hline
\end{tabular}

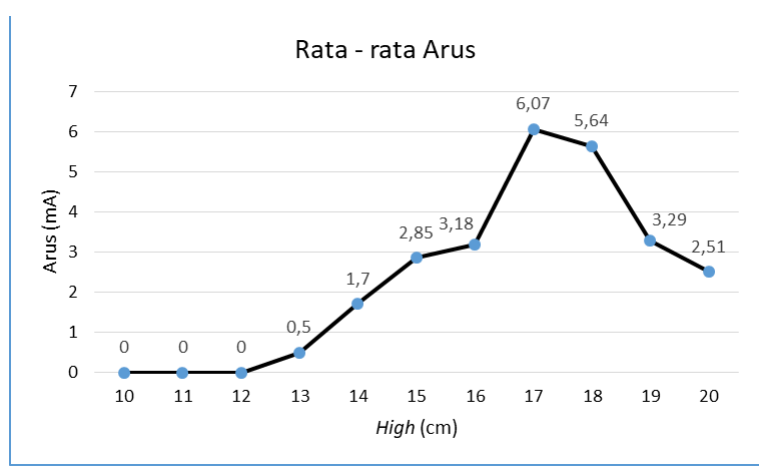

Gambar 13. Grafik Ketinggian Air Terhadap Arus

Berdasarkan Tabel 8 pengukuran rata-rata arus dan tegangan terhadap ketinggian air yang digunakan, tinggi air $17 \mathrm{~cm}$ menghasilkan arus maksimum sebesar 6,07 mA dan tegangan maksimum 3,03 Volt. Keadaaan ini diperoleh karena motor power window berada pada setpoint optimal, kemudian masih terdapat cukup ruang antara air dan kolam penampung air sehingga masih terdapat ruang bagi udara bertekanan untuk mengalir ke chamber yang terdapat turbin untuk memutar generator. Adapun nilai arus dan tegangan yang belum muncul pada awal pengujian diakibatkan belum adanya gelombang air yang tercipta dari motor power window, sehingga udara bertekanan belum cukup kuat untuk memutarkan bilah bilah turbin di dalam chamber.

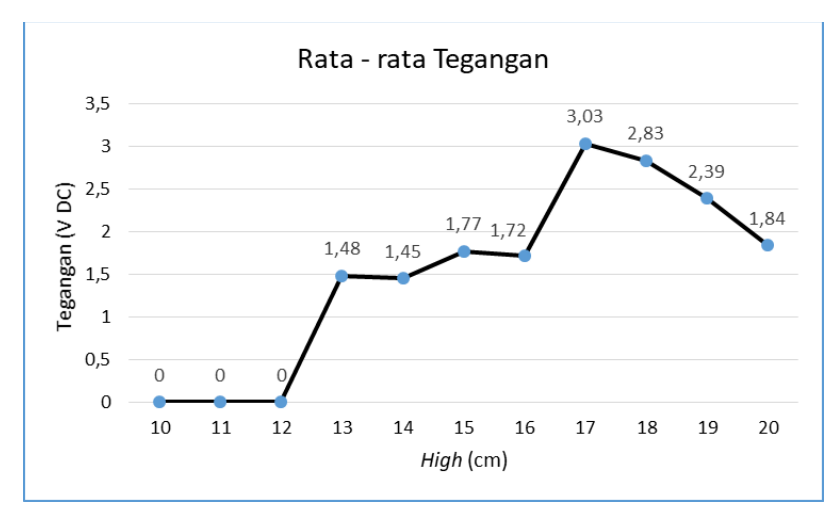

Gambar 14. Grafik Ketinggian Air Terhadap Tegangan

\section{Kesimpulan}

Prototipe pembangkit listrik tenaga gelombang laut (PLTGL) menggunakan sistem oscillating Water Column (OWC) menghasilkan arus sebesar 5,98 mA. dan tegangan yang dihasilkan adalah 3,05 V DC. Arus dan tegangan tersebut diperoleh dengan melakukan simulasi gelombang laut pada prototipe alat dengan parameter ketinggian air 17 $\mathrm{cm}$ dan volume air $0,0816 \mathrm{~m}^{3}$. Gelombang air sebagai simulasi gelombang air laut di pantai dihasilkan oleh dorongan air pada kolam penampung oleh motor power window dengan kecepatan putar maksimal yaitu 31,9 rpm. Hasil pengujian tersebut membuktikan bahwa potensi gelombang air dapat dimanfaatkan untuk menghasilkan listrik skala mikro.

Parameter yang perlu diperhatikan dalam simulasi PLTGL adalah tersedianya ruang yang cukup antara air dan kolam penampung air sehingga masih terdapat area bagi udara bertekanan untuk mengalir ke chamber untuk memutar turbin dan generator mampu membangkitkan listrik. Pengembangan kapasitas pembangkit listrik tenaga gelombang laut dapat dilakukan dengan menambah dimensi turbin dan menambah kapasitas generator.

\section{Daftar Pustaka}

[1] Haryadi, D., Notosudjono, D, and Soebagio, H., "Studi Potensi dan Teknologi Energi Laut Di Indonesia,” 2019.

[2] Eka Andhika Kurniawan, Annisa Aditsania, P.H. Gunawan, "Simulasi Gelombang Air Dangkal Untuk Pembangkit Energi Oscillating Water Column," E-Jurnal Matematika, vol.7 no.1, Jan. 2018, DOI: https://doi.org/10.24843/MTK.2018.v07.i01.p180.

[3] S. E. Bouji, Z. Beidouri and N. Kamil, "Design and Optimization of an Oscillating Water Column Wave Energy Converter," 2019 International Conference of Computer Science and Renewable Energies (ICCSRE), Agadir, Morocco, 2019, pp. 1-3, doi: 10.1109/ICCSRE.2019.8807608.

[4] Kurniawan, Luthfi P., Sarwito, S., Kusuma, I R., "Studi Perancangan Prototype Pembangkit Listrik Tenaga 
Gelombang Laut Tipe Salter Duck," Jurnal Teknik Pomits, vol.3, no.1, 2014.

[5] Haryani, T., Waydoyo, W., Abdullah Hidayat SA "Perencanaan Pembangkit Mikrohidro di Saluran Irigasi Mataram," Jurnal Hidroteknik, vol.2 no.1, 2015.

[6] Wijaya, I Wayan Arta, "Pembangkit Tenaga Gelombang Laut Menggunakan Teknologi Oscillating Water Column Di Perairan Bali," vol.9 no.2, jul.-Des. 2010.

[7] F. M'zoughi, S. Bouallègue and M. Ayadi, "Modeling and SIL simulation of an oscillating water column for ocean energy conversion," IREC2015 The Sixth International Renewable Energy Congress, Sousse, Tunisia, 2015, pp. 1-6, doi: 10.1109/IREC.2015.7110880.

[8] Seung Kwan Song and Jin Bae Park, "Apparatus and theory of a submerged point absorber using oscillating water column," 2013 OCEANS - San Diego, San Diego, CA, USA, 2013, pp. 1-5, doi: 10.23919/OCEANS.2013.6741110.

[9] M. Alberdi, M. Amundarain, A. J. Garrido, I. Garrido, O. Casquero and M. De la Sen, "Complementary Control of Oscillating Water Column-Based Wave Energy Conversion Plants to Improve the Instantaneous Power Output," in IEEE Transactions on Energy Conversion, vol. 26, no. 4, pp. 10211032, Dec. 2011, doi: 10.1109/TEC.2011.2167332.

[10] S. John Ashlin, S. A. Sannasiraj and V. Sundar, "An Experimental Study on Wave Forces and Pressures on an Oscillating Water Column Under Random Waves," OCEANS 2019 - Marseille, Marseille, France, 2019, pp. 1-7, doi: 10.1109/OCEANSE.2019.8867178

[11] Rais., Yudanto., Hadi, Eko Sasmito., Kiryanto, "Desain Konverter Gelombang Bentuk Tabung Sebagai Sumber Pembangkit Listrik di Perairan Laut Jawa," Jurnal Teknik Perkapalan, vol.4 no.2, 2016.
[12] Daryanto, Parjiman., Subekti, Massus., Rif'an, Muhammad., "Simulasi Gelombang Laut Untuk Pembangkit Listrik Tenaga Gelombang Laut (PLTGL)," Jurnal Teknologi Elektro, vol.9 no.2, Mei. 2018.

[13] Alim, Dwi Indra Abdulah, "Rancang bangun alat pembuat ombak buatan pada prototipe pembangkit listrik tenaga gelombang laut berbasis oscillating water column (OWC)," 2019.

[14] Azizie, Muhammad Rifki., Wicaksono, D A., Fitriana, "Analisis Energi Gelombang Air Laut Menggunakan Teknologi Oscillating Water Column," vol.2 no.1, Mar.2020, DOI: 10.32528/elkom.v2i1.3148.

[15] Valens Tae, Jahirwan Ut Jasron, Nurhayati, Verdy A Koehuan, "Perencanaan Turbin Wells Sistem Osilasi Kolom Air pada Pembangkit Listrik Tenaga Gelombang Laut dengan Kapasitas 10 kW," Jurnal Teknik Mesin UNDANA, vol. 2 no. 2, 2015.

[16] M. Malhouni and E. M. Boudi, "Modeling of hybrid system combining an offshore wind turbine and an Oscillating Water Column system," 2014 International Renewable and Sustainable Energy Conference (IRSEC), Ouarzazate, Morocco, 2014, pp. 836-839, doi: 10.1109/IRSEC.2014.7059816.

[17] K. Kevin, E. F. Simanjuntak, A. R. Utomo, F. Husnayain, F. H. Jufri and D. Riana Aryani, "Study on Micro-Scale Ocean Wave Power Generator Using Oscillating Water Column System with Piezoelectric," 2020 8th International Electrical Engineering Congress (iEECON), Chiang Mai, Thailand, 2020, pp. 1-4, doi: 10.1109/iEECON48109.2020.229502. 